\title{
Chapter 13 \\ Arbuscular Mycorrhizal Fungal \\ Communities of High Mountain \\ Ecosystems of South America: \\ Relationship with Microscale \\ and Macroscale Factors
}

Florencia Soteras, Eugenia Menoyo, Gabriel Grilli, and Alejandra G. Becerra

\subsection{Introduction}

South America harbors one of the main hotspots of diversity, the high mountain ecosystems, despite only accounting for a quarter of the Earth's land surface (Myers et al. 2000; Barry 2008; La Sorte and Jetz 2010; Hoorn et al. 2013). Several plants, birds, and macrofungal species show endemism in the high mountain of many regions of South America (Fjeldså and Kessler 1996; Myers et al. 2000; Robledo et al. 2006). These ecosystems comprise natural watersheds, providing several ecosystem services such as hydrological regime regulation, soil protection, and conservation of biodiversity (Grêt-Regamey et al. 2012). Mountain habitats show distinctive abiotic conditions that differentiate them from lowlands (Barry 2008). For instance, temperature decrease in average $6{ }^{\circ} \mathrm{C}$ per each $\mathrm{km}$ in elevation also influenced by latitude (Barry 2008). Generally, the studies in mountain ecosystems have been focused on aboveground diversity (plants, animals and macrofungi) (Robledo and Renison 2010; Castillo et al. 2017; Nouhra et al. 2018; Quintero and Jetz 2018), but little is known about soil communities (Lugo and Cabello 2002;

\footnotetext{
F. Soteras $(\bowtie)$

Laboratorio de Ecología Evolutiva y Biología Floral, IMBIV, CONICET, Universidad Nacional de Córdoba, Córdoba, Argentina

e-mail: fsoteras@conicet.gov.ar

E. Menoyo

Grupo de Estudios Ambientales, IMASL, CONICET, Universidad Nacional de San Luis, San Luis, Argentina

G. Grilli · A. G. Becerra

Laboratorio de Micología, IMBIV, CONICET, and Cátedra de Diversidad Biológica I, Facultad de Ciencias Exactas, Físicas y Naturales, Universidad Nacional de Córdoba, Córdoba, Argentina
} 
Becerra et al. 2009; Menoyo et al. 2009; Geml et al. 2014; Soteras et al. 2016). Among them, arbuscular mycorrhizal fungi (AMF) are ubiquitous root symbionts in the Glomeromycota that form an obligate root symbiosis with great part of land plants (Schüßler et al. 2001; Spatafora et al. 2006). Despite the large diversity of host plants (ca. 200,000 species), there has just been identified in average $250 \mathrm{AMF}$ morphological taxa (hereafter "morphospecies"), and no correlation between plant species and AMF richness has been globally found (Bever et al. 2001; Tedersoo et al. 2014).

The vast majority of the AMF taxa occur in nearly every climatic zones and continents (Davison et al. 2015). Last studies have postulated that a recent dispersion is the main factor shaping the cosmopolitan distribution of the most of the AMF taxa (Davison et al. 2015). However, these fungi are differentially affected by soil characteristics (Smith and Read 2008). In addition, different host species are colonized by particular AMF present in their rhizosphere (Senés-Guerrero and Schüßler 2016; Soteras et al. 2016), although there is a lack of a global positive correlation with plant richness. As plants and terrestrial animals, AMF taxa richness has been evidenced to correlate negatively with latitude (Hillebrand 2004; Davison et al. 2015), but different from ectomycorrhizal fungi (Tedersoo et al. 2014) and other soil microorganisms (Bardgett and Van Der Putten 2014). In addition, variables such as precipitation and temperature through the alteration of soil moisture, locally affect AMF richness (Davison et al. 2015). South America comprises diverse high mountain ecosystems, from low latitude tropical to high latitude temperate, where different local conditions also influence AMF communities (Matus et al. 2014).

Taxa of AMF could be grouped by their functional characteristics that are phylogenetically constrained (Hart and Reader 2002; Maherali and Klironomos 2007). Thereby, members of Gigasporaceae produce extensive extra-radical mycelia, sporulate lately in the growing season, and provide high nutritional benefits to hosts. On the other hand, Glomeraceae mainly colonize intraradically, produce spores early, and provide less nutritional benefits to hosts. Finally, Acaulosporaceae represents an intermediate colonization strategy, producing low biomass inside and outside the roots, and being highly resistant to soil acidity and low temperatures (Hart et al. 2001; Hart and Reader 2002). Accordingly, and based on the competitor-stress tolerant-ruderal framework of Grime (1979), Gigasporaceae are considered as "competitor", Glomeraceae as "ruderal" and Acaulosporaceae as "stress tolerant" (Chagnon et al. 2013).

In this chapter we reviewed and re-analyzed the data of the studies performed at high mountain ecosystems of South America to evaluate the variation of AMF morphospecies richness and composition of AMF communities in relation to micro- and macro-scale factors. Particularly, we hypothesized that high mountain forests harbor different richness and composition of AMF communities due to changes in microscale (host species, $\mathrm{pH}, \mathrm{N}, \mathrm{P}$ ) and macroscale factors (latitude, temperature, and precipitation) rather than similar AMF communities as expected from its cosmopolitan distribution. 


\subsection{Arbuscular Mycorrhizal Fungi in the High Mountain Ecosystems of South America}

Traditionally, the studies of AMF diversity were based on the morphological characteristics and ontogeny of the asexual spores (Smith and Read 2008). The advance of DNA-based methods improved the taxonomic identification of non-sporulating and AMF species. This kind of studies are very scarce in South America even more in mountain ecosystems (Soteras et al. 2016; Senés-Guerrero and Schüßler 2016). Therefore, we only considered the morphological diversity of AMF in high mountain ecosystems of South America. We compiled published studies searching in Google Scholar articles containing the following combination of terms: "arbuscular mycorrhizal" AND "high mountain" OR "Andean". We reviewed all the studies performed at mountain sites at around 1200 meters above sea level focusing on "highlands" sensu Barry (2008) that identified AMF spores morphologically. Following this procedure, we obtained in total 12 studies: 6 from Brazil, 5 from Argentina and 1 from Chile (Fig. 13.1, Table 13.1). Considering all of them, 168 AMF morphospecies were identified.

\subsection{Arbuscular Mycorrhizal Fungi Richness Versus Macroscale and Microscale Factors}

To disentangle the relationship of AMF richness with microscale and macroscale factors we fitted generalized linear models (GLM) with the $g \operatorname{lm}()$ function as implemented in the $\mathrm{R}$ environment with Poisson error distribution and identity logarithmic link function ( $\mathrm{R}$ Core Team 2018). When overdispersion was detected the standard errors were corrected using a quasi-GLM model (Zuur et al. 2009). Microscale factors included: host species or vegetation type and soil characteristics as $\mathrm{pH}, \mathrm{N}$ and $\mathrm{P}$ content, obtained from the studies when available. Macroscale factors included: latitude, mean annual temperature (in degree Celsius multiplied by 10) and mean annual precipitation from MERRAclim (Vega et al. 2017a), available in the DRYAD database (Vega et al. 2017b).

Vegetation type or host species showed significant differences in AMF rhizospheric richness (Fig. 13.2). Mountain ecosystems in Brazil (savanna forest, quartz gravel field dominated by Vellozia sp., and rocky outcrops of Cerrado and Atlantic Forest) showed the highest AMF richness. This result is probably due to the dominance of AMF in hot and seasonal environments (van der Heijden et al. 2008). For the contrary, the lowest AMF richness was observed in successional temperate forests of N. pumilio (Fig. 13.2). Generally, in temperate forests, where nutrient availability is low and the organic form is present in litter and humus, predominate the colonization by ectomycorrhizal decomposer fungi (Matus et al. 2014). In consequence, ectomycorrhizal fungi are responsible for almost the $80 \%$ of the $\mathrm{N}$ acquired by plants of temperate and boreal ecosystems (van der Heijden et al. 2008). As in $N$. 


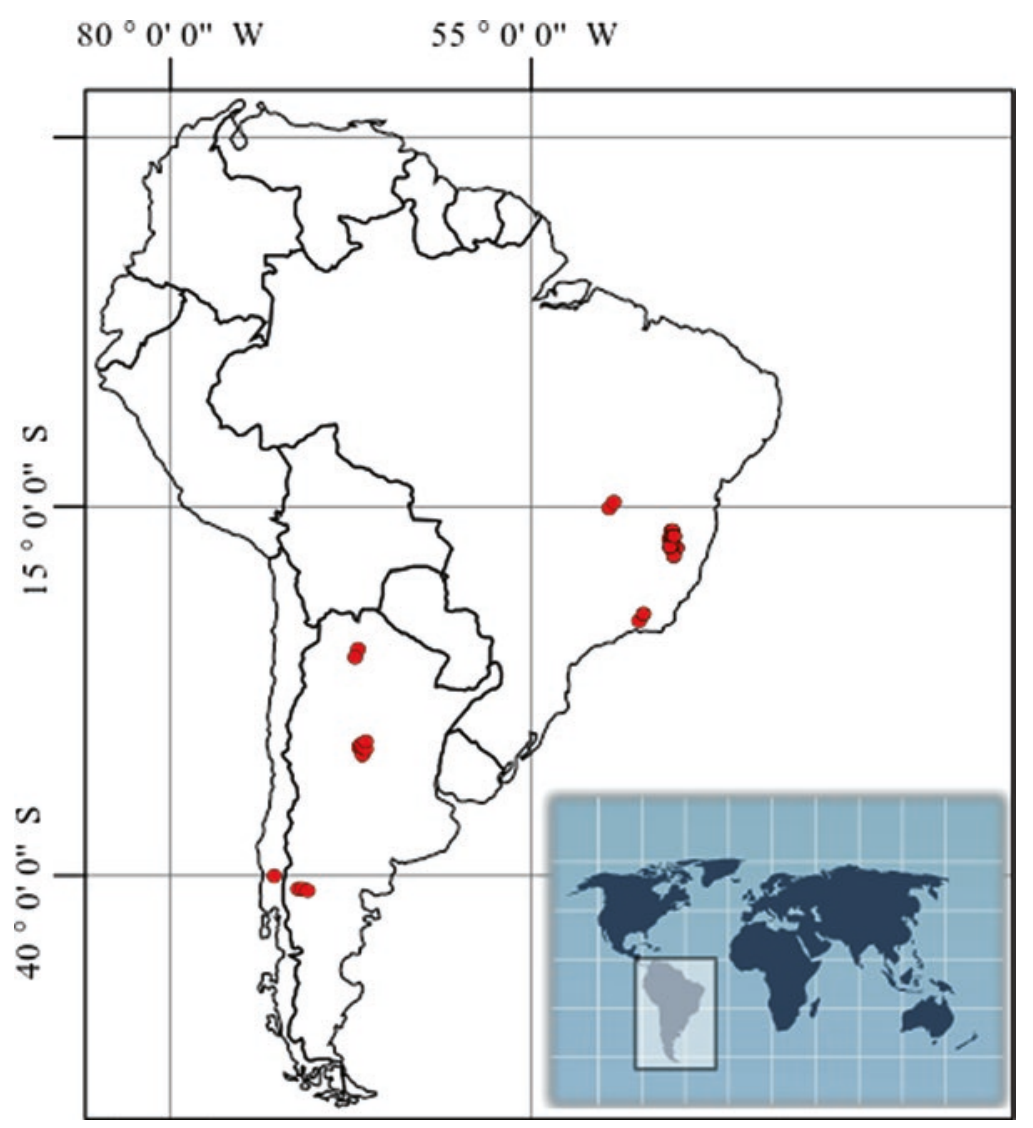

Fig. 13.1 Map showing the location of the high mountain ecosystems included in this study

pumilio forests, we found that reforested Araucaria forests of Brazil also showed a very low AMF diversity. In this study, rhizosphere soil samples were taken from reforested areas with A. angustifolia (8-12 years old) and Pinus elliotti plants (Moreira-Souza et al. 2003). Several studies have described changes in AMF communities associated with exotic plant invasion (Mummey and Rillig 2006). The very low AMF richness in this ecosystem compared with 19 other mountain hosts and ecosystems support the evidence that exotic plant species might negatively influence on soil AMF communities.

Arbuscular mycorrhizal fungi richness related to microscale $(\mathrm{pH}, \mathrm{N}$ and $\mathrm{P}$ content) and macroscale (latitude, mean annual temperature and mean annual precipitation) factors are shown in Fig. 13.3. AMF richness was negatively related to $\mathrm{pH}$ $(\mathrm{t}=2.049, \mathrm{P}=0.046$, Fig. 13.3a), positively to $\mathrm{N}(\mathrm{t}=3.003, \mathrm{P}=0.006$, Fig. 13.3b), but not significant relationship was observed with $P(t=0.236, P=0.81$, Fig. 13.3c $)$. In addition, a negative relationship was observed of AMF richness with latitude in absolute numbers $(\mathrm{t}=-4.015, \mathrm{P}<0.001$, Fig. 13.3d), and a positive relationship 


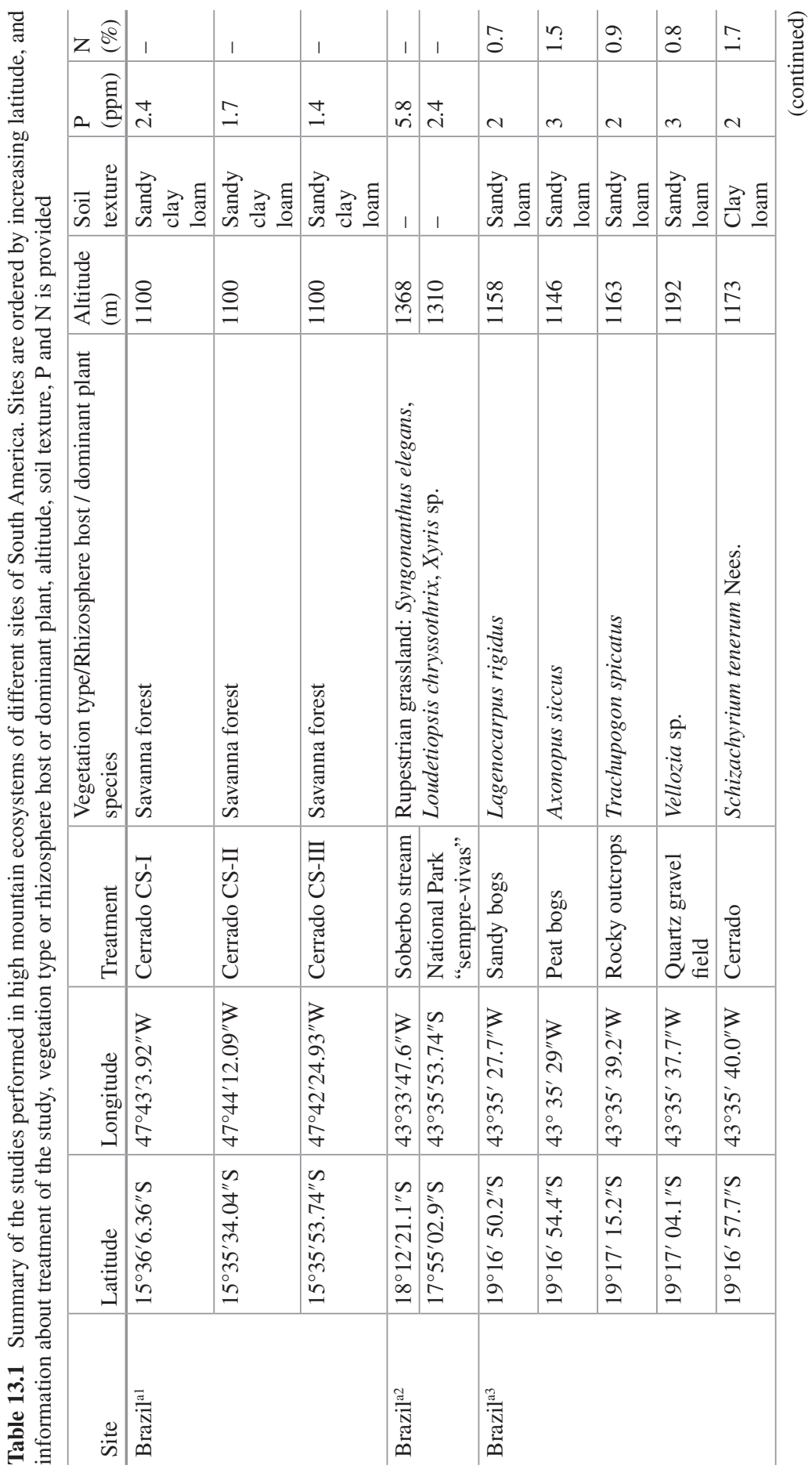




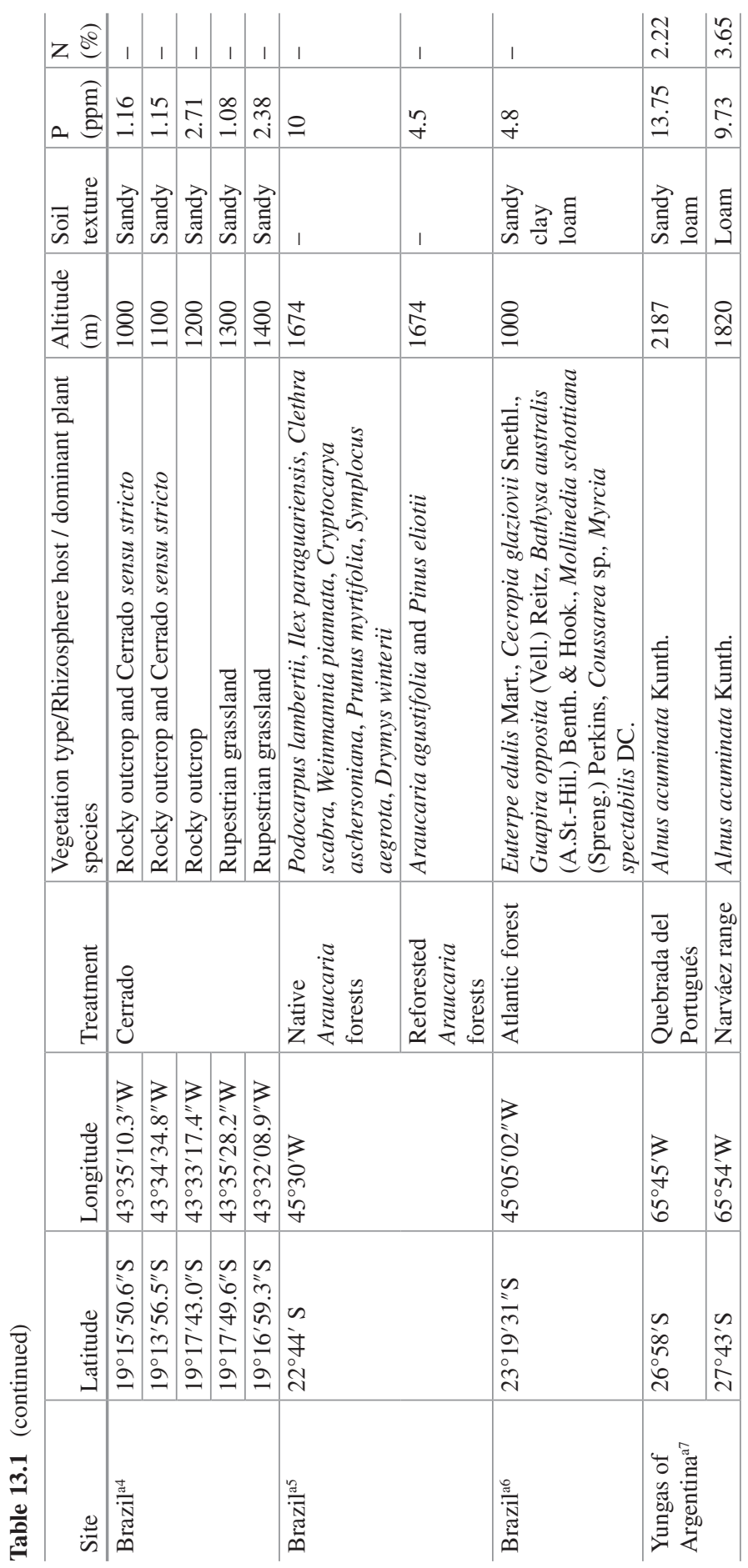




\begin{tabular}{|c|c|c|c|c|c|c|}
\hline$z \stackrel{e}{e}$ & 苟 & ڤั) & $\stackrel{0}{0}$ & $\stackrel{1}{0}$ & $=$ & 1 \\
\hline ค ڤ્气 & $\begin{array}{l}\infty \\
\infty \\
0 \\
\wp\end{array}$ & $\begin{array}{c}\text { ñ } \\
\text { mे }\end{array}$ & $\stackrel{m}{\stackrel{m}{+}}$ & $\frac{1}{0}$ & $\stackrel{n}{\varrho}$ & 1 \\
\hline 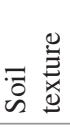 & 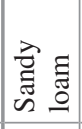 & 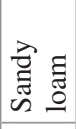 & 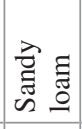 & 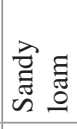 & 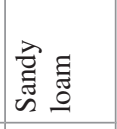 & 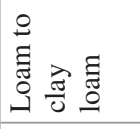 \\
\hline$\stackrel{\frac{8}{E}}{\stackrel{\Xi}{E}}$ & $\begin{array}{ll}1 & 0 \\
\infty & 8 \\
\infty & 0\end{array}$ & $\begin{array}{l}1 \\
\delta\end{array}$ & 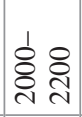 & $\frac{\text { I }}{\text { d }}$ & $\frac{\curvearrowright}{\grave{2}}$ & $\begin{array}{l}\stackrel{2}{n} \\
\text { ה̃ }\end{array}$ \\
\hline 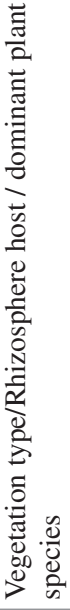 & 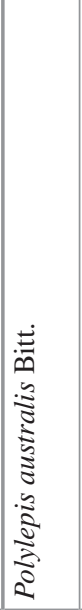 & 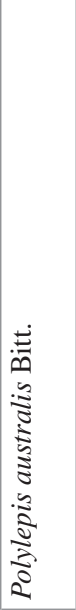 & 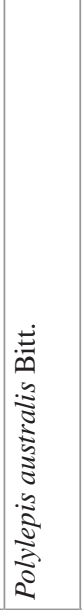 & 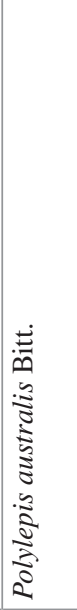 & 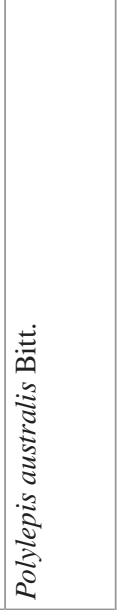 & 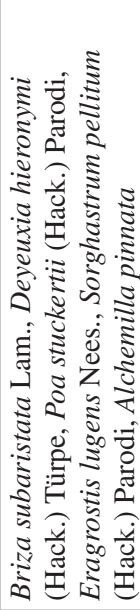 \\
\hline 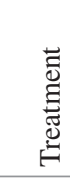 & $\begin{array}{l}0 \\
0 \\
0 \\
0 \\
0 \\
0 \\
0 \\
1\end{array}$ & 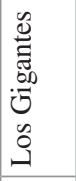 & 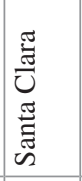 & 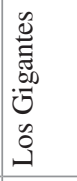 & 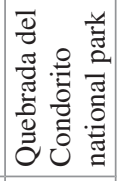 & 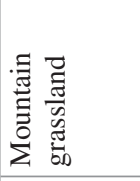 \\
\hline 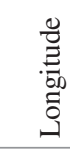 & $\begin{array}{l}3 \\
0 \\
2 \\
0 \\
0\end{array}$ & $\begin{array}{l}3 \\
\infty \\
0 \\
0 \\
0 \\
0\end{array}$ & \begin{tabular}{l}
3 \\
\multirow{2}{*}{} \\
0 \\
0 \\
3
\end{tabular} & \begin{tabular}{l}
3 \\
\multirow{8}{*}{} \\
0 \\
0
\end{tabular} & $\begin{array}{l}3 \\
a \\
q \\
0 \\
0\end{array}$ & $\begin{array}{l}3 \\
\text { in } \\
y \\
0 \\
0\end{array}$ \\
\hline 莺 & $\begin{array}{l}n \\
\infty \\
n \\
0 \\
n\end{array}$ & 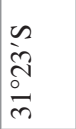 & $\begin{array}{l}\frac{m}{n} \\
\frac{9}{7} \\
\frac{n}{0}\end{array}$ & $\begin{array}{l}n \\
i \\
i \\
0 \\
0 \\
m\end{array}$ & $\begin{array}{l}n \\
i \\
m \\
0 \\
n\end{array}$ & $\begin{array}{l}n \\
0 \\
\text { ñ } \\
0 \\
0\end{array}$ \\
\hline 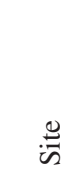 & 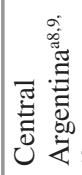 & & & & & \\
\hline
\end{tabular}




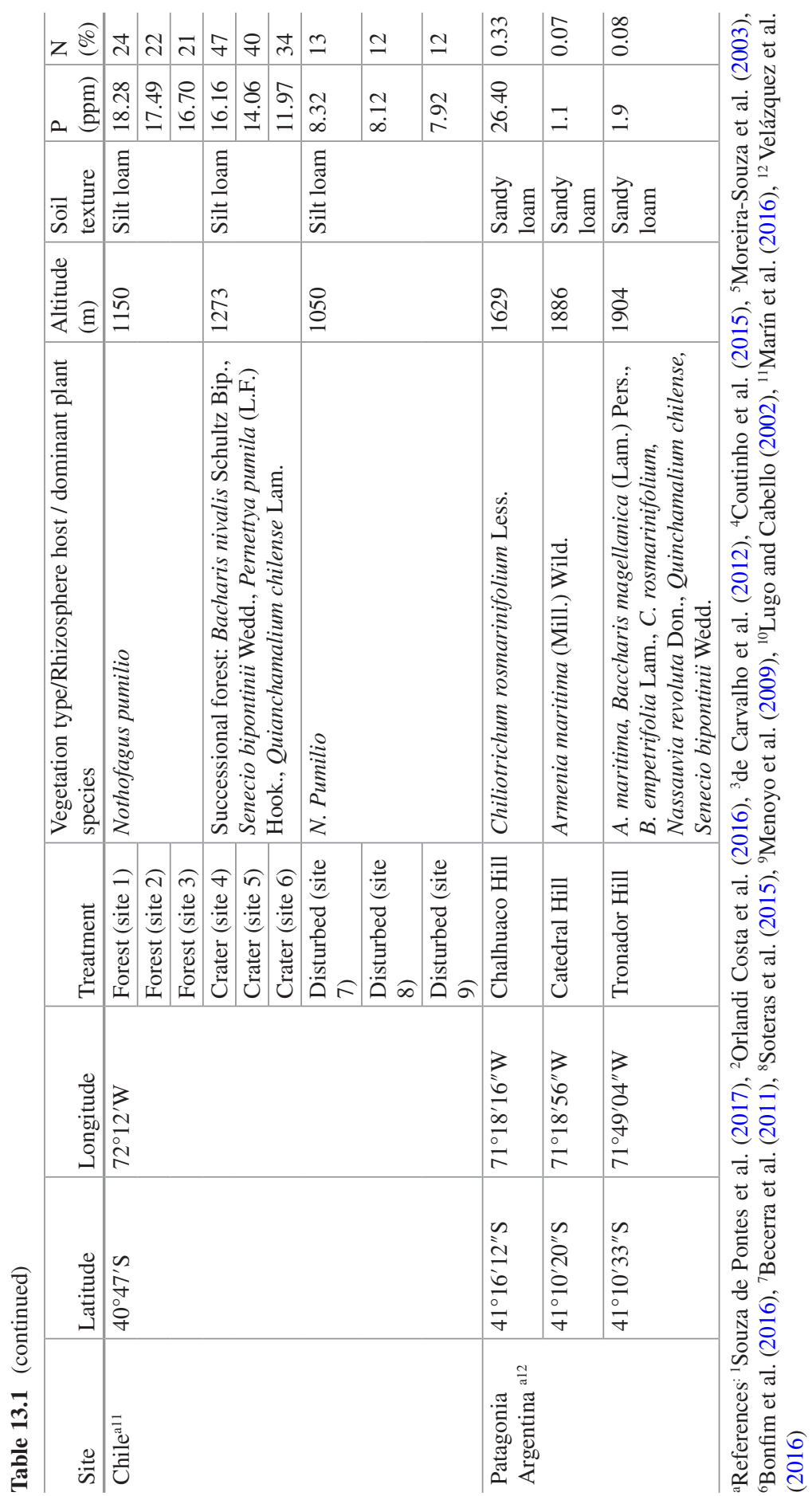




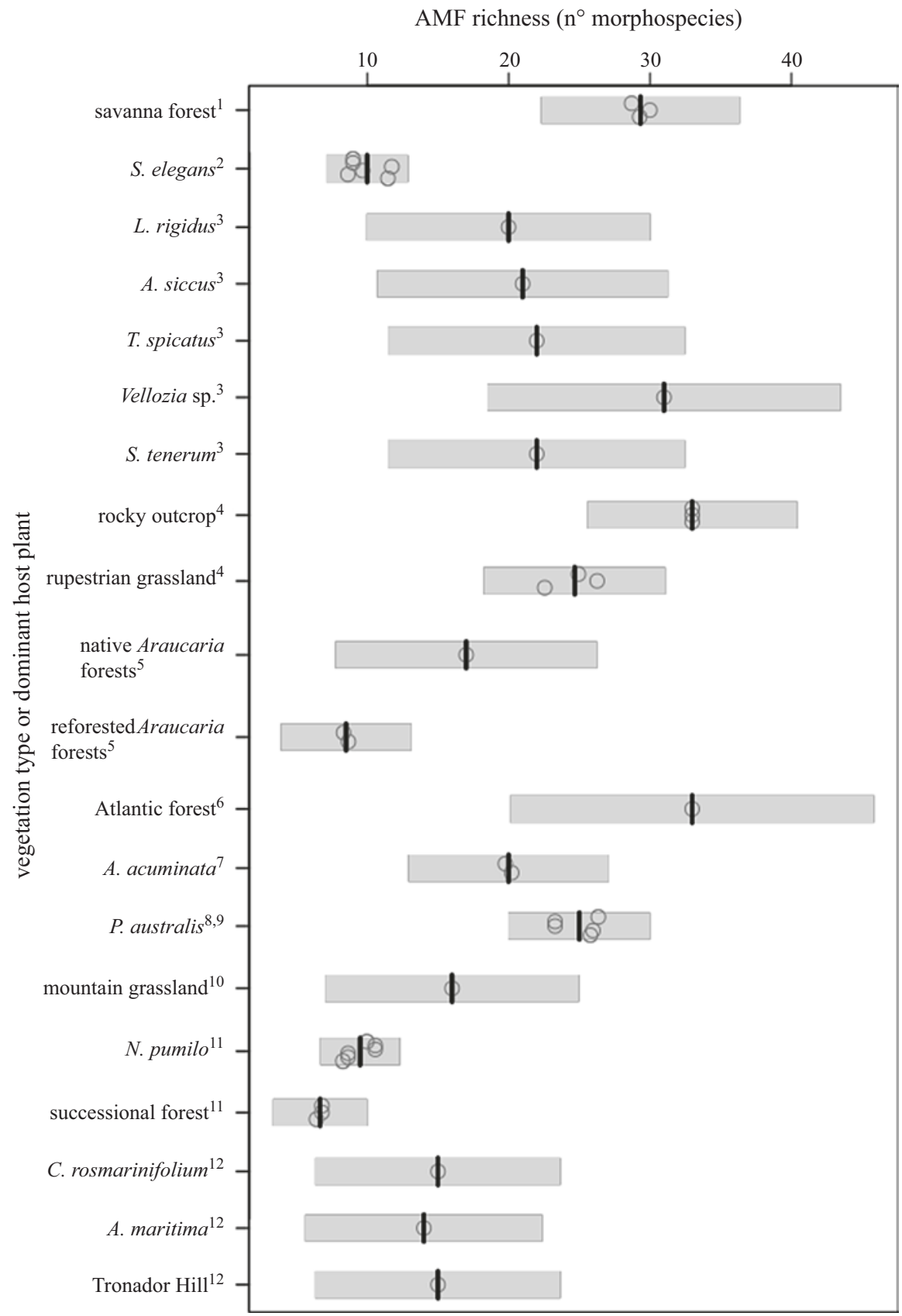

Fig. 13.2 AMF richness related to vegetation type or dominant host plant (ordered by increasing latitude) 
a

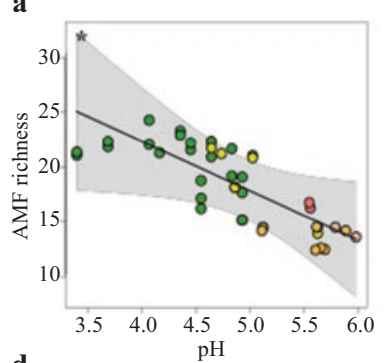

d

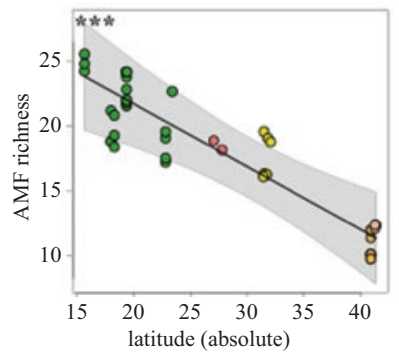

- Brazil

- Yungas

- Chile

- Patagonia Argentina

- Central Argentina

b
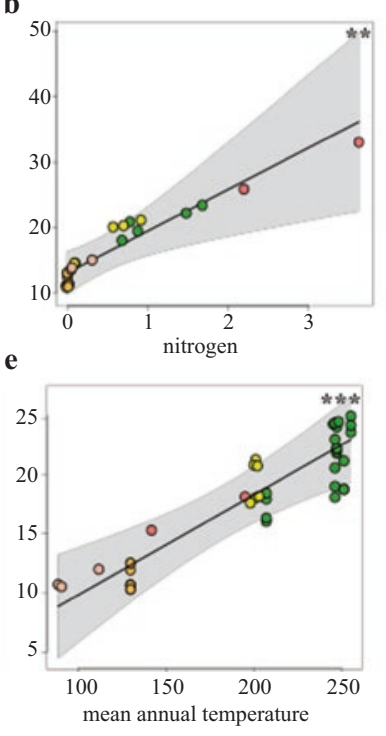

c
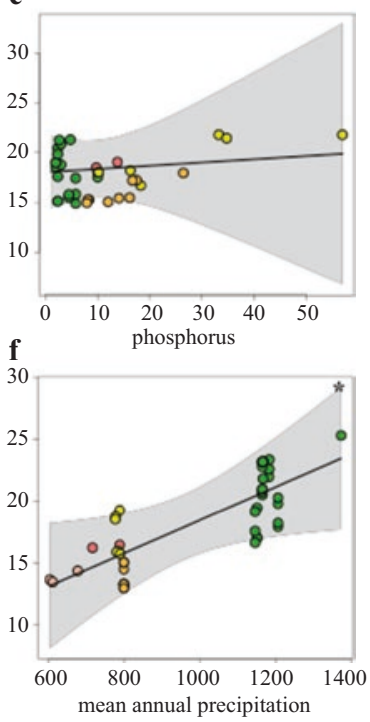

Fig. 13.3 AMF richness related to microscale ( $\mathrm{pH}, \mathrm{N}$ and $\mathrm{P}$ content) and macroscale (latitude, mean annual temperature and mean annual precipitation) factors. Asterisks indicate significant relationship according to the GLM $(* * * \mathrm{P}<0.001$, ** $\mathrm{P}<0.01$, $* \mathrm{P}<0.05)$. Points color represents sampling sites

with both mean annual temperature $(\mathrm{t}=4.191, \mathrm{P}<0.001$, Fig. 13.3e $)$ and precipitation $(\mathrm{t}=2.137, \mathrm{P}=0.039$, Fig. 13.3f). AMF communities of high mountain showed high richness at lower latitudinal tropical ecosystems, where seasonal changes of solar radiation, day length and temperature are small (Barry 2008). These ecosystems showed the lowest $\mathrm{pH}$ and intermediate $\mathrm{N}$ values. The same latitudinal pattern was observed for global AMF richness studies (Davison et al. 2015), plants and animals (Hillebrand 2004), but not for ectomycorrhizal fungi which are associated with specific forest types (Tedersoo et al. 2014).

\subsection{Arbuscular Mycorrhizal Fungi Communities' Composition: Geographical Structure and Relationship with Macroscale Factors}

In order to evaluate the variation on $\mathrm{AMF}$ community composition in relation to different geographical scales and macroscale factors, we first constructed principal coordinates of neighbor matrices (PCNM). The PCNM variables allow to detect if 
the biological response (i.e. AMF community composition) is associated with different spatial structures along the study area. We obtained six geographical variables able to detect the spatial structure of the data at all scales encompassed by the sampling design (Borcard and Legendre 2002; Borcard et al. 2004). The order of the PCNM variables follows a progression from larger to smaller spatial scales (Borcard et al. 2004). For each response data model, the most significant PCNM variables were chosen by permutational forward model selection and ensuring that the adjusted $\mathrm{R}^{2}$ of the reduced models did not exceeded the adjusted $\mathrm{R}^{2}$ of the global models. The AMF community composition (presence-absence) was partitioned among the selected geographical variables and macroscale factors (latitude, mean annual temperature and mean annual precipitation) using distance-based redundancy analysis (db-RDA), with capscale() function from R package vegan (Legendre and Andersson 1999; Oksanen et al. 2018). The dissimilarity distance between pairs of AMF morphospecies was estimated using the Sorensen index. The variation explained by geographical variables and macroscale factors was determined by the automatic selection of variables using forward model choice on adjusted $\mathrm{R}^{2}$ with 999 permutations using the ordiR2step() function. In this procedure, the variables that best fit the data are sequentially selected and added to the final model. The analyses were performed using the vegan package in R. The significance among centroids of sites was assessed with the envfit() function of the vegan package after 999 permutations. To determine whether the significant effects were attributed to either differences of multivariate site (between group variability) or to dispersion (within group variability) we used the betadisper() function of vegan. Microscale factors were not included in this analysis due to missing data in some sites. The Yungas, Cerrado and Soberbo stream from Brazil (Orlandi Costa et al. 2016; Souza de Pontes et al. 2017) were discarded from the db-RDA analysis due to significant effect of within heterogeneity, which avoids the possibility to differentiate the effects of multivariate dispersion from the compositional change among sites.

Four geographical variables were significantly structuring AMF communities (ordered in increasing importance for final model fit: $\mathrm{PCNM} 1: \mathrm{F}=17.737, \mathrm{P}=0.002$; PCNM3: $\mathrm{F}=11.047, \mathrm{P}=0.002 ; \mathrm{PCNM} 4: \mathrm{F}=4.779, \mathrm{P}=0.002$; and $\mathrm{PCNM} 2$ : $\mathrm{F}=2.697, \mathrm{P}=0.018)$. The three macroscale variables significantly structured AMF community composition of each site (latitude: $\mathrm{F}=19.899, \mathrm{P}=0.002$; mean annual precipitation: $\mathrm{F}=92.853, \mathrm{P}=0.002$; and mean annual temperature: $\mathrm{F}=5.532$, $\mathrm{P}=0.002$ ) being kept in the final model. Site differences in relation to their AMF community was associated $25 \%$ with both geographical and macroscale factors $\left(R^{2}=0.72\right.$, pseudo- $F=12.32, P=0.001$, Fig. $\left.13.4 a\right), 21 \%$ with only geographical factors $\left(\mathrm{R}^{2}=0.59\right.$, pseudo-F $=12.35, \mathrm{P}=0.001$, Fig. $\left.13.4 \mathrm{~b}\right)$, and $19 \%$ with only macroscale factors $\left(\mathrm{R}^{2}=0.55\right.$, pseudo- $\mathrm{F}=13.63, \mathrm{P}=0.001$, Fig. $\left.13.4 \mathrm{c}\right)$.

According to the analysis derived from the db-RDA, the AMF community differed significantly among sites $\left(r^{2}=0.94, P<0.001\right.$, Fig. 13.4a). At a wider scale (represented by PCNM1; associated with db-RDA1: $\mathrm{r}^{2}=0.95, \mathrm{P}=0.001$ ), latitude, precipitation and temperature were highly related to differences between Brazil and Chile in their AMF community composition. This is in concordance with global studies of AMF biogeography that showed influences of temperature and precipitation on AMF root colonizing composition (Öpik et al. 2013; Davison et al. 2015). 


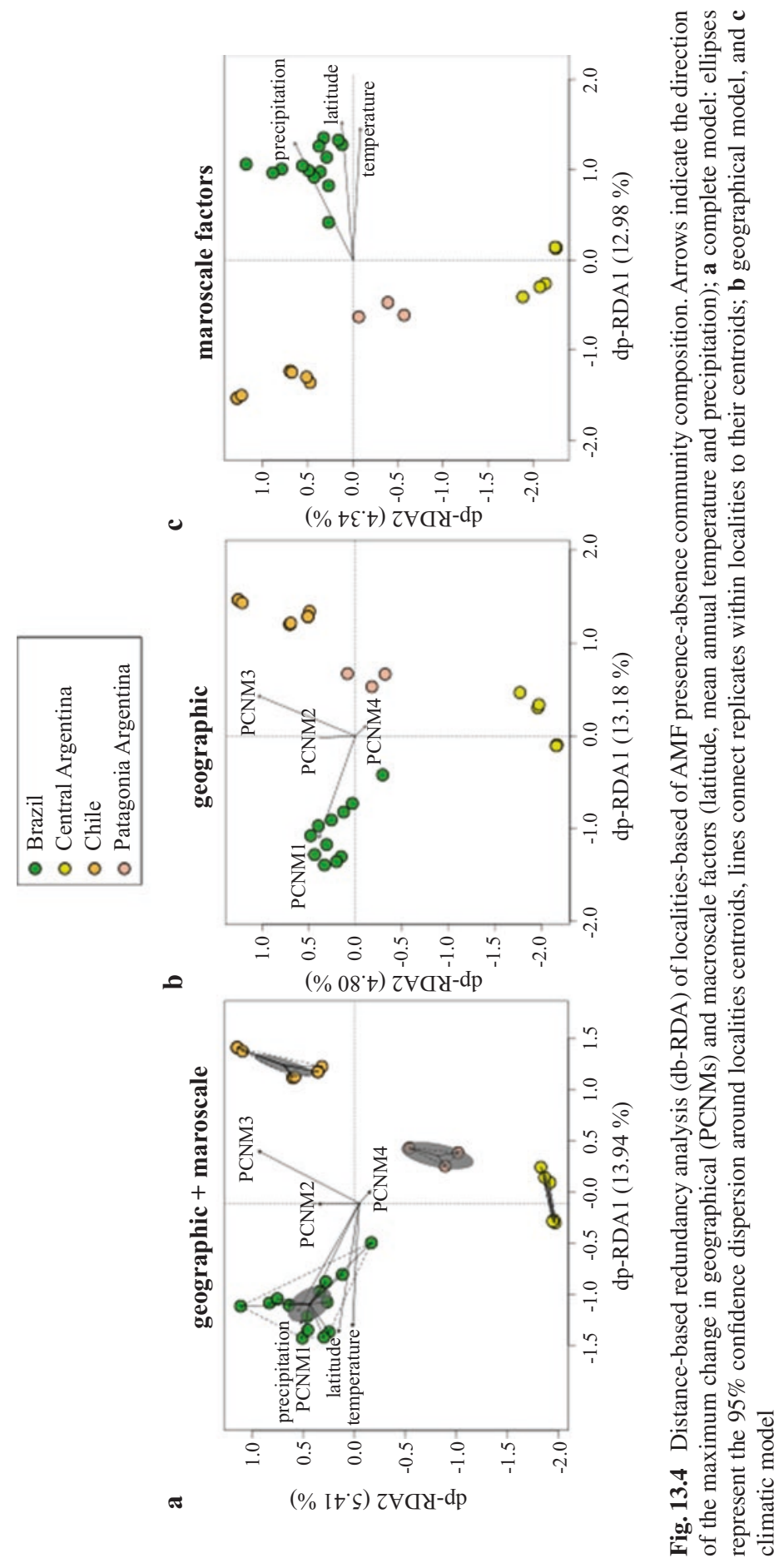


At coarse scales (mainly represented by PCNM3; associated with db-RDA2: $r^{2}=0.66, P=0.001$ ) Central Argentina and Patagonia Argentina differentiated in their AMF community composition mainly due to the differences in host species (PERMANOVA: $\mathrm{F}=12.54, \mathrm{r}^{2}=0.77, \mathrm{P}=0.001$ ), soil $\mathrm{pH}$ (PERMANOVA: $\mathrm{F}=10.53, \mathrm{r}^{2}=0.47, \mathrm{P}=0.001$ ) and $\mathrm{N}$ content (PERMANOVA: $\mathrm{F}=7.678, \mathrm{r}^{2}=0.39$, $\mathrm{P}=0.001)$. Several studies provide evidence that the distribution of AMF can be affected by host species, pH and total N (Koske 1987; Johnson et al. 1992; EgertonWarburton et al. 2004).

To evaluate the strength of association of sampling sites, and vegetation type or dominant host with AMF morphospecies, an indicator species analysis was applied using the indval() function of the R package labdsv (Dufrene and Legendre 1997; Roberts 2013). Two species were significantly associated with Brazil, nine with Yungas, eleven with Central Argentina, three with Chile, and six with Patagonia. Of the 20 vegetation types and dominant hosts, six AMF morphospecies were significantly associated with savanna forest, one with A. siccus, one with $T$. spicatus, four with rocky outcrop, one with rupestrian grassland, one with $A$. acuminata, four with P. australis, three with N. pumilio, and one with successional forest. A meta-analysis of global distribution patterns of root-colonizing AMF also demonstrated different type of ecosystems hosting different assemblages of AMF morphospecies (Öpik et al. 2006).

\subsection{Relationship Between AMF Functional Richness and Abiotic Characteristics}

Arbuscular mycorrhizal fungi were grouped into three functional groups according to their traits (sensu Chagnon et al. 2013): "ruderal-Glomeraceae" (Claroideoglomeraceae + Glomeraceae + Pacisporaceae + Diversisporaceae), "stress-tolerant-Acaulosporaceae" (Acaulosporaceae + Ambisporaceae + Entrophosporaceae + Archaeosporaceae), and "competitor-Gigasporaceae". To determine the relationship among AMF functional groups with microscale and macroscale factors we fitted generalized linear models (GLM) with the $g \operatorname{lm}()$ function as implemented in the R environment with Poisson error distribution and identity or logarithmic, in the case of Gigasporaceae, link function. When overdispersion was detected, the standard errors were corrected using a quasi-GLM model.

Glomeraceae and Gigasporaceae families were negatively associated with $\mathrm{pH}$ $(\mathrm{t}=3.685, \mathrm{P}<0.001 ; \mathrm{t}=2.785, \mathrm{P}=0.009$; respectively $)$. Meanwhile, and contrary to previous evidence (Veresoglou et al. 2012), Acaulosporaceae did not show a significant relationship with $\mathrm{pH}(\mathrm{t}=0.747, \mathrm{P}=0.460)$. Glomeraceae and Gigasporaceae showed higher morphospecies richness in soils with $\mathrm{pH}$ between 3.5 and 5.0, and Acaulosporaceae from 5.0 to 6.0. Contrary to Glomeraceae, sporulation of Acaulosporaceae is promoted in acidic soils, but its members also occur on higher pH soils (Clark 1997). Only Gigasporaceae showed a significant and positive asso- 
ciation with $\mathrm{N}(\mathrm{t}=5.106, \mathrm{P}<0.001)$, and a negative association with $\mathrm{P}(\mathrm{t}=2.038$, $\mathrm{P}=0.048)$. Meanwhile, Glomeraceae and Acaulosporaceae did not show a significant relationship with any of these variables (Fig. 13.5). In P- limited ecosystems with high $\mathrm{N}$ availability, host plants may select AMF taxa with extensive hyphal networks that forage $\mathrm{P}$ effectively, such as Gigasporaceae (Egerton-Warburton et al. 2007). This is because excess in $\mathrm{N}$ availability is expected to improve plant photosynthesis thus making the availability of $\mathrm{C}$ for transfer to AMF symbionts less costly for the plant (Johnson 2010). Nonetheless, evidence that increase $\mathrm{N}$ availability reduce the occurrence of AMF taxa with greater $\mathrm{P}$ benefit (i.e. Gigasporaceae) has been also documented (Treseder et al. 2018).

Among macroscale factors, Glomeraceae and Gigasporaceae showed a negative significant relationship with latitude $(\mathrm{t}=4.450, \mathrm{P}<0.001 ; \mathrm{t}=5.180, \mathrm{P}<0.001$; respectively), and a positive association with mean annual temperature $(\mathrm{t}=5.302$, $\mathrm{P}<0.001 ; \mathrm{t}=3.902, \mathrm{P}<0.001$; respectively $)$ and precipitation $(\mathrm{t}=2.779, \mathrm{P}=0.008$; $\mathrm{t}=3.815, \mathrm{P}<0.001$; respectively). However, Acaulosporaceae did not show significant association with any of these variables (Fig. 13.5). Gigasporaceae members are adapted to live in stable ecosystems (de Souza et al. 2005), and highly dependent on precipitation (Veresoglou et al. 2012) as observed here.

\subsection{Conclusions}

High mountain ecosystems of South America differed in their AMF communities due to macroscale and microscale factors, revealing indicator AMF morphospecies associated with either sampling site or vegetation type or host identity. This is in line with global molecular studies of AMF, which evidenced patchily distributed AMF communities (Öpik et al. 2010, 2013), although contrary to an AMF taxa cosmopolitan distribution (Davison et al. 2015). As stated by Davison et al. (2015), several high mountain ecosystems of South America remain unexplored thus making our results probably related to low sampling effort. However, it is important to take into account that these authors presented global patterns of molecularly identified AMF species considering only four records among grassland and successional forests at South America thus probably losing the patchily structure of AMF communities of high mountain ecosystems. The AMF richness relationships with micro and macroscale factors were mainly due to Glomeraceae and Gigasporaceae responses to these variables. At higher scales, tropical and temperate ecosystems differentiated in their AMF community composition due to macroscale factors as latitude, precipitation and temperature. At lower scales, soil characteristics and host species became the most relevant factors in differentiating AMF community composition of sites. High mountain ecosystems of South America comprise a particular environment in which AMF communities could not be framed in a cosmopolitan pattern but rather they adjust to their own pattern associated with specific conditions of the highlands. 
13 Arbuscular Mycorrhizal Fungal Communities of High Mountain Ecosystems...

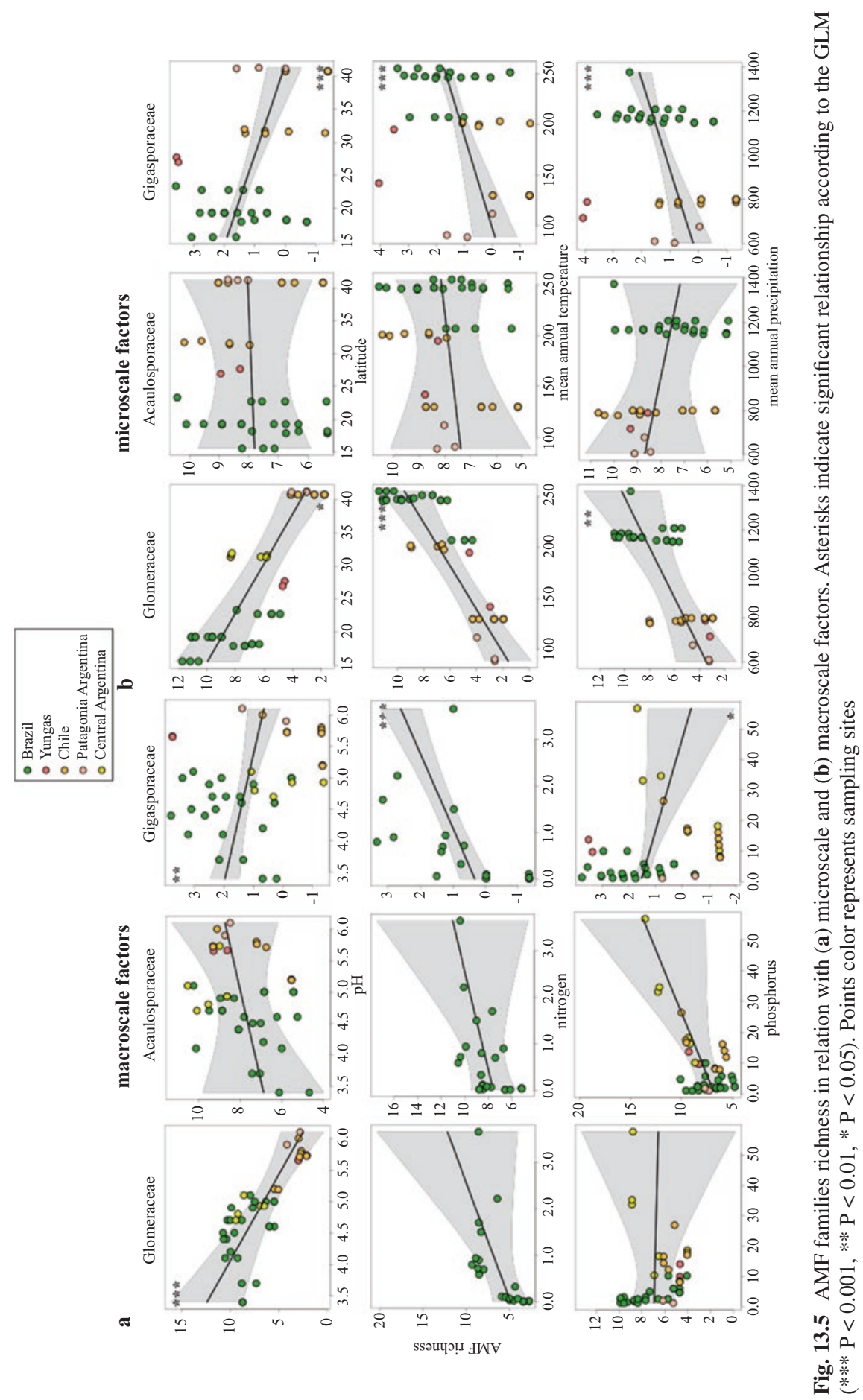


Acknowledgements This work was financially supported by FONCyT (BID PICT 438-2006 granted to A.B., BID 2015 PICT 338 granted to F.S), and Idea Wild Foundation. All authors are staff researchers from CONICET.

\section{References}

Bardgett RD, Van Der Putten WH (2014) Belowground biodiversity and ecosystem functioning. Nature 515(7528):505-511

Barry RG (2008) Mountain weather and climate. Third edit, Mountain Weather and Climate, Third Edition. Third edit. New York: Cambridge University Press

Becerra AG, Cabello MN, Bartoloni NJ (2011) Native arbuscular mycorrhizal fungi in the Yungas forests, Argentina. Mycologia 103(2):273-279

Becerra AG, Cabello M, Zak MR, Bartoloni N (2009) Arbuscular mycorrhizae of dominant plant species in Yungas forests, Argentina. Mycologia 101(5):612-621

Bever JD, Schultz PA, Pringle A, Morton JB (2001) Arbuscular mycorrhizal fungi: More diverse than meets the eye, and the ecological tale of why. BioScience 51(11):923-931

Bonfim JA, Vasconcellos RLF, Gumiere T, de Lourdes Colombo Mescolotti D, Oehl F, Nogueira Cardoso EJB (2016) Diversity of arbuscular mycorrhizal fungi in a Brazilian Atlantic Forest toposequence. Microb Ecol 71(1):164-177

Borcard D, Legendre P (2002) All scale spatial analysis of ecological data by means of principal coordinates of neighbor matrices. Ecol Model 153:51-68

Borcard D, Legendre P, Avois-Jacquet C, Tuomisto H (2004) Dissecting the spatial structure of ecological data at multiple scales. Ecology 85(7):1826-1832

Castillo DD, Carrasco JC, Quevedo LA, Ricaurte CB, Gavilanes AV, Borz SA (2017) Diversity, composition and structure of Andean High Forest in Ecuador, South America. Bull Transilvania University Braşov 10(59):1-16

Chagnon P-L, Bradley RL, Maherali H, Klironomos JN (2013) A trait-based framework to understand life history of mycorrhizal fungi. Trends Plant Sci 18(9):484-491

Clark RB (1997) Arbuscular mycorrhizal adaptation, spore germination, root colonization, and host plant growth and mineral acquisition at low pH. Plant Soil 192:15-22

Coutinho ES, Fernandes GW, Berbara RLL, Valério HM, Goto BT (2015) Variation of arbuscular mycorrhizal fungal communities along an altitudinal gradient in rupestrian grasslands in Brazil. Mycorrhiza 25(8):627-638

Davison J, Moora M, Öpik M, Adholeya A, Ainsaar L, Bâ A, Burla S, Diedhiou AG, Hiiesalu I, Jairus T, Johnson NC, Kane A, Koorem K, Kochar M, Ndiaye C, Pärtel M, Reier Ü, Saks Ü, Singh R, Vasar M, Zobel M (2015) Global assessment of arbuscular mycorrhizal fungus diversity reveals very low endemism. Science 127(6251):970-973

de Carvalho F, de Souza FA, Carrenho R, de Souza Moreira FM, da Conçeição Jesus E, Wilson Fernandes G (2012) The mosaic of habitats in the high-altitude Brazilian rupestrian fields is a hotspot for arbuscular mycorrhizal fungi. Appl Soil Ecol 52:9-19

de Souza F, Dalpé Y, Declerck S, de la Providencia I, Séjalon-Delmas N (2005) Life History Strategies in Gigasporaceae: Insight from Monoxenic Culture. In: Declerck S, Fortin JA, Strullu DG (eds) In Vitro Culture of Mycorrhizas. Springer, Berlin, Heidelberg, p 73-91

Dufrene M, Legendre P (1997) Species assemblages and indicator species: the need for a flexible asymmetrical approach. Ecol Monogr 67(3):345-366

Egerton-Warburton LM, Allen EB, Allen MF (2004) Conservation of mycorrhizal fungal communities under elevated atmospheric $\mathrm{CO} 2$ and anthropogenic nitrogen deposition. In: Sivasithamparama K, Dixon KW, Barret RL (eds) Microorganisms in plant conservation and biodiversity. Springer, Netherlands, p 19-43 
Egerton-Warburton LM, Johnson NC, Allen EB (2007) Mycorrhizal community dynamics following nitrogen fertilization: a cross-site test in five grasslands. Ecol Monogr 77(4):527-544

Fjeldså J, Kessler M (1996) Conserving the biological diversity of Polylepis woodlands of the highland of Peru and Bolivia. A contribution to sustainable natural resource management in the Andes. Copenhagen, Denmark: Nordeco

Geml J, Pastor N, Fernandez L, Pacheco S, Semenova T, Becerra AG, Wicaksono CY, Nouhra ER (2014) Large-scale fungal diversity assessment in the Andean Yungas forests reveals strong community turnover among forest types along an altitudinal gradient. Mol Ecol 23(10):2452-2472

Grêt-Regamey A, Brunner SH, Kienast F (2012) Mountain ecosystem services: Who cares?. Mount Res Dev 32(S1):S23-S34

Grime JP (1979) Plant Strategies and Vegetation Processes. John Wiley \& Sons, Chichester, New York, Brisbane,Toronto

Hart MM, Reader RJ (2002) Taxonomic basis for variation in the colonization strategy of arbuscular mycorrhizal fungi. New Phytol 153:335-344

Hart MM, Reader RJ, Klironomos JN (2001) Life-history strategies of arbuscular mycorrhizal fungi in relation to their successional dynamics. Mycologia 93(6):1186-1194

van der Heijden MGA, Bardgett RD, van Straalen NM (2008) The unseen majority: soil microbes as drivers of plant diversity and productivity in terrestrial ecosystems. Ecol Lett 11(3):296-310

Hillebrand $\mathrm{H}$ (2004) On the Generality of the Latitudinal Diversity Gradient. Am Nat 163(2):192-211

Hoorn C, Mosbrugger V, Mulch A, Antonelli A (2013) Biodiversity from mountain building. Nature Geoscience. Nature Publishing Group, a division of Macmillan Publishers Limited. All Rights Reserved, 6, p 154

Johnson NC (2010) Resource stoichiometry elucidates the structure and function of arbuscular mycorrhizas across scales. New Phytol 185(3):631-647

Johnson NC, Tilman D, Wedin D (1992) Plant and soil controls on mycorrhizal fungal communities. Ecology 73(6):2034-2042

Koske RE (1987) Distribution of VA mycorrhizal fungi along a latitudinal temperature gradient. Mycologia 79(1):55-68

La Sorte FA, Jetz W (2010) Projected range contractions of montane biodiversity under global warming. Proc R Soc Biol Sci Ser B 277(1699):3401-3410

Legendre P, Andersson MJ (1999) Distance-based redundancy analysis: Testing multispecies responses in multifactorial ecological experiments. Ecol Mon 69(1):1-24

Lugo MA, Cabello MN (2002) Native arbuscular mycorrhizal fungi (AMF) from mountain grassland (Cordoba, Argentina) I. Seasonal variation of fungal spore diversity. Mycologia 94(4):579-586

Maherali H, Klironomos JN (2007) Influence of phylogeny on fungal community assembly and ecosystem functioning. Science 316(5832):1746-1748

Marín C, Aguilera P, Cornejo P, Godoy R, Oehl F, Palfner G, Boy J (2016) Arbuscular mycorrhizal assemblages along contrasting Andean forests of Southern Chile. J soil Sci plant Nutr 16(4):916-929

Matus F, Rumpel C, Neculman R, Panichini M, Mora ML (2014) Soil carbon storage and stabilisation in andic soils: A review. Catena 120:102-110

Menoyo E, Renison D, Becerra AG (2009) Arbuscular mycorrhizas and performance of Polylepis australis trees in relation to livestock density. For Ecol Manag 258(12):2676-2682

Moreira-Souza M, Trufem SFB, Gomes-Da-Costa SM, Cardoso EJ (2003) Arbuscular mycorrhizal fungi associated with Araucaria angustifolia (Bert.) O. Ktze. Mycorrhiza 13(4):211-215

Mummey DL, Rillig MC (2006) The invasive plant species Centaurea maculosa alters arbuscular mycorrhizal fungal communities in the field. Plant Soil 288(1-2):81-90

Myers N, Mittermeier RA, Mittermeier CG, da Fonseca GAB, Kent J (2000) Biodiversity hotspots for conservation priorities. Nature 403(6772):853-858

Nouhra E, Soteras F, Pastor N, Geml J (2018) Richness, species composition and functional groups in Agaricomycetes communities along a vegetation and elevational gradient in the Andean Yungas of Argentina. Biodivers Conserv 27(8):1849-1871 
Oksanen J, Blanchet FG, Friendly M, Kindt R, Legendre P, McGlinn D, Minchin PR, O'Hara RB, Simpson GL, Solymos P, Stevens MHH, Szoecs E, Wagner H (2018) vegan: Community Ecology Package. R package version 2.5-2. https://CRAN.R-project.org/package=vegan

Öpik M, Moora M, Liira J, Zobel M (2006) Composition of root-colonizing arbuscular mycorrhizal fungal communities in different ecosystems around the globe. Journal of Ecology 94(4):778-790

Öpik M, Vanatoa A, Vanatoa E, Moora M, Davison J, Kalwij JM, Reier U, Zobel M (2010) The online database MaarjAM reveals global and ecosystemic distribution patterns in arbuscular mycorrhizal fungi (Glomeromycota). New Phytol 188(1):223-241

Öpik M, Zobel M, Cantero JJ, Davison J, Facelli JM, Hiiesalu I, Jairus T, Kalwij JM, Koorem K, Leal ME, Liira J, Metsis M, Neshataeva V, Paal J, Phosri C, Põlme S, Reier Ü, Saks Ü, Schimann H, Thiéry O, Vasar M, Moora M (2013) Global sampling of plant roots expands the described molecular diversity of arbuscular mycorrhizal fungi. Mycorrhiza 23(5):411-430

Orlandi Costa HA, Stürmer SL, Ragonezi C, Grazziotti PH, Fonseca Santos Grazziotti DC, de Barros Silva E (2016) Species richness and root colonization of arbuscular mycorrhizal fungi in Syngonanthus elegans, an endemic and threatened species from the Cerrado domain in Brazil. Ciência Agrotecnologia 40(3):326-336

Quintero I, Jetz W (2018) Global elevational diversity and diversification of birds. Nature 555:246-250

R Core Team (2018) R: A language and environment for statistical computing. R Foundation for Statistical Computing, Vienna, Austria. http://www.R-project.org.

Roberts DW (2013) labdsv: ordination and multivariate analysis for ecology package. Version 1.6-1. http://cran.r-project.org/web/packages/labdsv

Robledo GL, Renison D (2010) Wood-decaying polypores in the mountains of central Argentina in relation to Polylepis forest structure and altitude. Fungal Ecology 3(3):178-184

Robledo G, Urcelay C, Domínguez L, Rajchenberg M (2006) Taxonomy, ecology, and biogeography of polypores (Basidiomycetes) from Argentinian Polylepis woodlands. Can J Bot 84(10):1561-1572

Schüßler A, Schwarzott D, Walker C (2001) A new fungal phylum, the Glomeromycota: phylogeny and evolution. Mycol Res 105(12):1413-1421

Senés-Guerrero C, Schüßler A (2016) A conserved arbuscular mycorrhizal fungal core-species community colonizes potato roots in the Andes. Fungal Divers 77(1):317-333

Smith SE, Read D (2008) Mycorrhizal symbiosis. Academic Press, Great Britain

Soteras F, Grilli G, Cofré MN, Marro N, Becerra A (2015) Arbuscular mycorrhizal fungal composition in high montane forests with different disturbance histories in central Argentina. Appl Soil Ecol 85:30-37

Soteras F, Coutinho Moreira B, Grilli G, Pastor N, Carneiro Mendes F, Ruela Mendes D, Renison D, Megumi Kasuya MC, de Souza FA, Becerra A (2016) Arbuscular mycorrhizal fungal diversity in rhizosphere spores versus roots of an endangered endemic tree from Argentina: Is fungal diversity similar among forest disturbance types?. Appl Soil Ecol 98:272-277

Souza de Pontes JS, Oehl F, Donizete Pereira C, Torres de Toledo Machado C, Coyne D, Alves da Silva DK, Maia LC (2017) Diversity of arbuscular mycorrhizal fungi in the Brazilian's Cerrado and in soybean under conservation and conventional tillage. Appl Soil Ecol 117-118:178-189

Spatafora JW, Sung G-H, Johnson D, Hesse C, O'Rourke B, Serdani M, Spotts R, Lutzoni F, Hofstetter V, Miadlikowska J, Reeb V, Gueidan C, Fraker E, Lumbsch T, Lücking R, Schmitt I, Hosaka K, Aptroot A, Roux C, Miller AN, Geiser DM, Hafellner J, Hestmark G, Arnold AE, Büdel B, Rauhut A, Hewitt D, Untereiner WA, Cole MS, Scheidegger C, Schult M, Sipman H, Schoch CL (2006) A five-gene phylogeny of Pezizomycotina. Mycologia 98(6):1018-1028

Tedersoo L, Bahram M, Põlme S, Kõljalg U, Yorou NS, Wijesundera R, Ruiz L. V, Vasco-Palacios AM, Thu PQ, Suija A, Smith ME, Sharp C, Saluveer E, Saitta A, Rosas M, Riit T, Ratkowsky D, Pritsch K, Põldmaa K, Piepenbring M, Phosri C, Peterson M, Parts K, Pärtel K, Otsing E, Nouhra E, Njouonkou AL, Nilsson RH, Morgado LN, Mayor J, May TW, Majuakim L, Lodge DJ, Lee SS, Larsson K-H, Kohout P, Hosaka K, Hiiesalu I, Henkel TW, Harend H, Guo L, 
Greslebin A, Grelet G, Geml J, Gates G, Dunstan W, Dunk, Drenkhan R, Dearnaley J, De Kesel A, Dang T, Chen X, Buegger F, Brearley FQ, Bonito G, Anslan S, Abell S, Abarenkov K (2014) Global diversity and geography of soil fungi. Science 346(6213): 1256688-1-10

Treseder KK, Allen EB, Egerton-Warburton LM, Hart MM, Klironomos JN, Maherali H, Tedersoo, L (2018) Arbuscular mycorrhizal fungi as mediators of ecosystem responses to nitrogen deposition: A trait-based predictive framework. J Ecol 106(2):480-489

Vega GC, Pertierra LR, Olalla-Tárraga MÁ (2017a) MERRAclim, a high-resolution global dataset of remotely sensed bioclimatic variables for ecological modelling. Scientific Data 4:1-12

Vega GC, Pertierra L, Olalla-Tárraga M (2017b) Data from: MERRAclim, a high-resolution global dataset of remotely sensed bioclimatic variables for ecological modelling. Dryad Digital Repository

Velázquez MS, Stürmer SL, Bruzone C, Fontenla S, Barrera M, Cabello M (2016) Occurrence of arbuscular mycorrhizal fungi in high altitude sites of the Patagonian Altoandina region in Nahuel Huapi National Park (Argentina). Acta Bot Brasilica 30(4):521-531

Veresoglou SD, Chen B, Rillig MC (2012) Arbuscular mycorrhiza and soil nitrogen cycling. Soil Biol Biochem 46:53-62

Zuur AF, Ieno NI, Walker NJ, Saveliev AA, Smith MG (2009) Mixxed effects models and extensions in ecology with R, Gail M, Krickeberg K, Samet JM, Tsiatis A, Wong W (eds). Springer, Verlag, New York 